\title{
THE CURIOUS CASE OF PM CARES FUND: CORPORATE SOCIAL RESPONSIBILITY AND THE SUPPRESSION OF CIVIL SOCIETY IN INDIA
}

\author{
Panya Chakravarty ${ }^{1}$ and Sumedha Bose ${ }^{2}$ \\ ${ }^{1}$ Tata Institute of Social Sciences \\ ${ }^{2}$ Mumbai , Hong Kong University
}

DOI: 10.46609/IJSSER.2021.v06i03.025 URL: https://doi.org/10.46609/IJSSER.2021.v06i03.025

"In a pluralistic society like ours, I think the ability to resist hate comes from cultivating a civil society that, on the one hand, nurtures the freedom of each group to pursue their faith and distinctive way of life, while, at the same time, fostering the ties that bind us together into a genuine broader community" - William Barr

\section{POLICY CLIMATE FOR CIVIL SOCIETY IN INDIA}

According to B Baviskar, India is gradually morphing into a society which is characterised by the decline of the state and the increasing prominence of the role of Civil Society Organisations (CSO) (Baviskar, 2001). Indeed, the role of CSOs has significantly increased in nation building, as compared to the period right after independence, when the State was largely responsible for delivering fundamental services such as water supply, healthcare, education, sanitation etc. to its citizens. Today, with over 3 million registered Non Governmental Organizations (NGOs) in the country, many of these services are largely being provided by NGOs and other forms of civil society.

The vast ambit of the term civil society is diverse and dynamic. Over the years, it has evolved and moved well beyond its traditional interpretation as an NGO dominated 'sector' (WEF, 2013, p. 5). Today, it includes a myriad of organized and unorganized groups with different configurations, that aim to combat social challenges. These include both registered nonprofits/foundations and voluntary associations at various administrative levels, which form important networks that work towards societal justice. A comprehensive definition of civil society has been proposed by the World Bank as :

"the wide array of non-governmental and not-for-profit organizations that have a presence in public life, expressing the interests and values of their members or others, based on 


\section{International Journal of Social Science and Economic Research}

ISSN: $2455-8834$

Volume:06, Issue:03 "March 2021"

ethical, cultural, political, scientific, religious or philanthropic considerations. Civil society organizations therefore refer to a wide array of organizations: community groups, NGOs, labour unions, indigenous groups, charitable organizations, faith-based organizations, professional associations, and foundations." (WEF, 2013)

The state, market and civil society constitute the collective life force of development. However, civil society has always been considered as "the area outside the family, market and state"(WEF, 2013, p. 5). Being considered as a distinct and distanced entity from these important institutions of society, has led many to believe that CSOs are beyond the scope of regulation. This misconception has potentially exposed it to criticism from various sections of the public, about accountability, funding and their general value addition to society (Cooper, R., 2018). As a result, there has been a pushback from various governments who have tried to curtail the powers and undermine the voice of civil society in their respective countries.

For some time now, a global debate has been raging about 'closing space for civil society'. Civil society has from the start been a champion of democracy, fighting to ensure the people have an array of freedoms including the freedom to oppose the government. So when Freedom House, a U.S.-based organization that conducts research and advocacy on democracy, political freedom, and human rights, noted a decline in global freedom for the 13th consecutive year as published in their annual report, this raised alarms for CSOs across the world. We have seen violation of human rights on a global scale, accompanied by attempts to stifle rising voices of dissent across the world.

India has drawn international attention in recent times with its ruthless crackdown on civic freedoms. Under the Modi government, which has been in power since 2014, India has seen an alarming rise in communal tensions, arrests of journalists, mob lynchings and misuse of the Unlawful Activities (Prevention) Act (1967) to put elements of the opposition behind bars. More recently, the country witnessed police brutality against student protestors exercising their right to protest against the Citizenship Amendment Act (2019) and National Register for Citizens exercise. The former has been accused of being a discriminatory law_which offers citizenship to migrants belonging to any major South Asian faith except for Islam, while the latter, many believe is a diabolical exercise to single out minorities and paint them as illegal immigrants in the country, as as a basis to revoke their citizenship.

CIVICUS, a global civil society alliance that monitors civil society freedoms across the globe, has downgraded India from a country with 'obstructed' civic space to one with 'repressed'. A short idea of what the two respective ranks is conveyed through their scale. According to this, a graphical representation of which you will find below, 'obstructed' signifies a state of affairs where 'civic space is heavily contested by power holders, who impose a combination of legal 
and practical constraints on the full enjoyment of fundamental rights', while 'repressed' speaks of constrained civil society where 'active individuals and civil society members who criticise power holders risk surveillance, harassment, intimidation, imprisonment, injury and death'.

COUNTRIES PER RATING CATEGORY

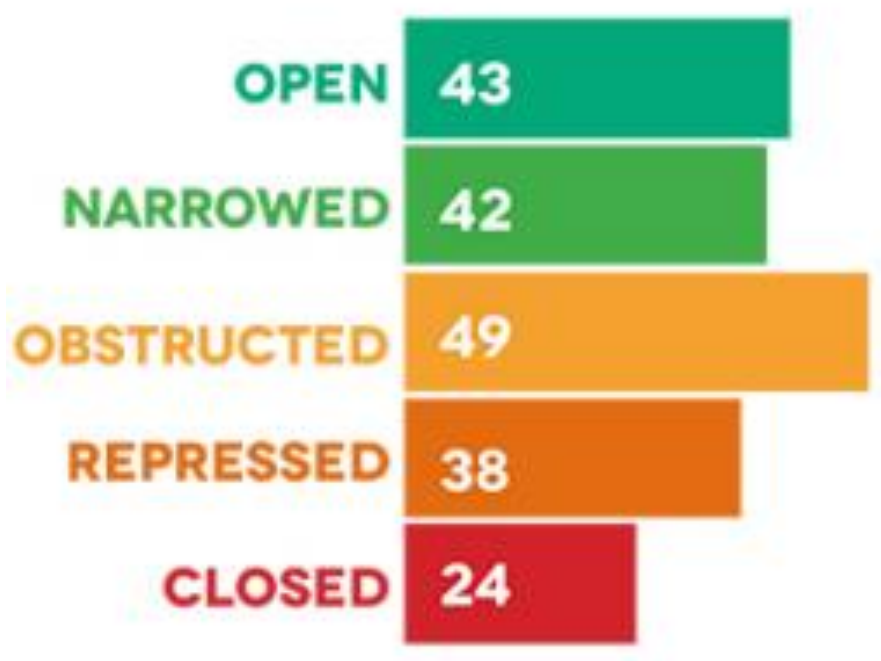

COUNTRY RATINGS CHANGES

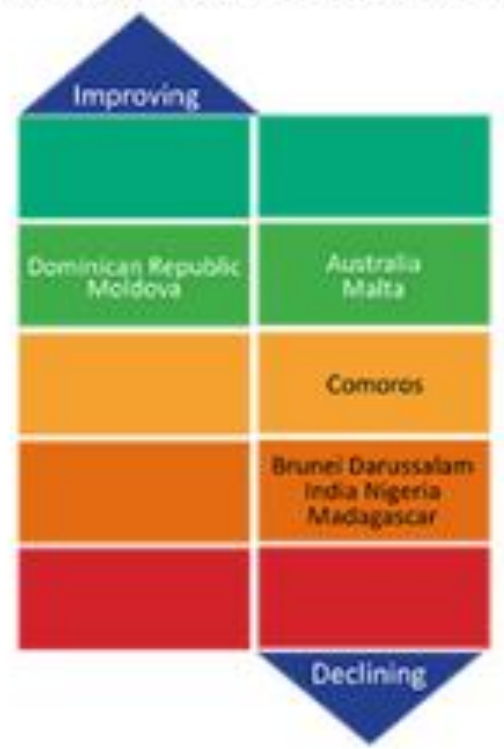

CIVICUS Monitor - Tracking Civic Space

As we mentioned earlier, the rise of police brutality_in the country, misusing legal instruments such as the UAPA(2019) to shut out opposing voices, and more such disturbing incidents have caused India to slip further down on the CIVICUS index, and has provided a clear indication of the 'closing space for civil society' in the country.

\section{THEN AND NOW; USE OF THE FCRA}

The hostile regulatory environment towards civil society can be traced back to the Indira Gandhi regime and the subsequent implementation of Foreign Contributions (Regulation) Act in 1976, during the emergency. The act was introduced as a regulatory instrument to oversee acceptance and use of foreign contributions and endowments by any individual, association or company in the country, and to also prohibit the acceptance of such contributions in case they were being used to fund activities which the government felt was detrimental to national interests. The act prohibited political parties, judges, MPs and cartoonists alike from accepting foreign aid.

The implementation of FCRA was justified by the fear of the 'foreign hand' taking over Indian politics in the context of the cold war. Although foreign powers taking hold over domestic institutions was an alarming issue at the time, this law was used as a tool to curb political dissent 


\section{International Journal of Social Science and Economic Research}

ISSN: $2455-8834$

Volume:06, Issue:03 "March 2021"

of opponents at home. This skepticism was further strengthened by Dr. Manmohan Singh in a 2012 interview, when he asserted the involvement of the foreign hand in many campaigns led by civil society. This was immediately followed by increased scrutiny of NGOs that were receiving foreign funding, and the probing of 77 NGOs that were receiving foreign aid from Europe and USA. Further, he also criticised NGOs receiving support from abroad for stalling the 'developmental agenda' which included private acquisitions and forest clearances by leading protests (Nayar, 2014). The allegation was made at a time when businesses were desecrating natural resources, which was fiercely contested by several environmental activists and tribal communities in Odisha, Jharkhand and Chattisgarh. Subsequently, the government painted these protests as anti-development.

This was the opportune moment for the 'leak' of a report by the Intelligence Bureau, which estimated the economic damage caused by NGOs to domestic development at 2-3\% of the GDP (Nayar, 2014). The crackdown on GreenPeace India for its alleged anti-developmental activities by undertaking protests against nuclear and thermal power and mining in 2013, was probed by the Intelligence Bureau report (2014). Furthermore, the report accused anti-GMO activists and NGOs such as Greenpeace of stalling mega industrial projects of Vedanta.

Interestingly, in 2014, the Delhi High Court found the Indian National Congress Party (INC) and Bharatiya Janata Party (BJP) guilty of accepting foreign funding from Vedanta subsidiaries in violation of FCRA. Instead of any action being taken against the two parties, the act was amended and a finance act was passed in 2016 by BJP, without debate. The amendments to the act made the regulatory climate more stringent than ever before, particularly towards CSOs, as NGOs had to now renew their registration every five years. This amendment also proposed to redefine what constituted as a foreign company, and any company could be classified as "Indian"- if its ownership was tied to an Indian entity. These so called 'Indian' companies were allowed to contribute within foreign investment limits, made retrospective from 2010 onwards, thus allowing political parties to accept foreign donations.

Another major change brought about by the amendment was that it now allowed the government to dictate how civil society spends its money by setting a cap of $50 \%$ on administrative spending. While earlier the act aimed towards limiting foreign funding received by political parties, now it included organisations of 'political nature'. The list of organisations included workers unions, women's wings of political parties, farmers and youth organizations, which again, pointed towards the selective use of this act to curb political dissent. In 2019, the Rajya Sabha reported that 14,500 NGOs were banned by the government from receiving foreign funding since 2014, while 1,808 had their licenses revoked in 2019 itself (Sampath, 2016). 


\section{International Journal of Social Science and Economic Research}

ISSN: $2455-8834$

Volume:06, Issue:03 "March 2021"

Having ratified the International Covenant on Civil and Political Rights (ICCPR) in 1979, the Indian government proceeded to undermine freedom of associations advocated in the treaty, as the ability "to seek, receive and use resources - human, material and financial - from domestic, foreign, and international sources" has been curtailed for CSOs. It has been observed for years now, that the Indian government has not taken kindly to CSOs receiving foreign aid, which have been portrayed as attempts by foreign governments to meddle in India's affairs.

Presently, the continued arbitrary use of FCRA by the Modi government prompted leading activists to claim that the act was being used as a strategic tool by the government, to dry up funding channels of prominent civil society institutions. The present government has already revoked the licenses of more than 20,000 nongovernmental organizations, ever since it came to power in 2014. As a result, several CSOs got together to write an open letter to the Centre, condemning the "arbitrary and undemocratic move by the MHA." The letter, which included signatories such as Amnesty International India, Greenpeace India, TARSHI Delhi, the Delhi Drug Users Forum, Centre for Social Justice, Lawyers Collective and many such eminent organizations, claimed that "the state is following a systematic and sustained agenda of suppressing those very dissenting voices that have consistently challenged the system."

The list which contains names of the organizations who have had their FCRA licenses revoked arbitrarily, features the names of certain prominent organizations doing incredible work for minorities. Many of the organizations_on the list who have had their licenses revoked, work closely with minority groups. Some have claimed that the government is following a pick and choose policy where NGOs working specifically for Hindu welfare are receiving grants. This points to a systemic bias in the current government which has been severely criticised for spreading propaganda regarding India being a 'Hindu Rashtra'.

Along with bureaucratic opposition, minorities are also facing social backlash. In the last few years, radical Hindu nationalists have led a hate campaign of cow vigilantism, wherein people from Dalit and Muslim communities have been mob lynched based on suspicion of beef consumption and cow trading. It received global attention and even propelled Human Rights Watch to write a report on 'Violent Cow Protection in India.'

The attacks which affected Dalit and Muslim communities disproportionately, saw many CSOs advocate for strict action against perpetrators. Once of these organizations is Navsarjan Trust, a Dalit rights organization which led massive protests against the indiscriminatory lynching of Dalits, majority of whom skin dead animals and sell hides to earn their livelihoods. Soon enough, the federal government canceled the foreign funding license of the Trust, claiming that they were "working against public interest" and painting the Modi government as anti-Dalit abroad'. 
International Journal of Social Science and Economic Research

ISSN: 2455-8834

Volume:06, Issue:03 "March 2021"

One can concur that the policy climate in India has been largely hostile towards CSOs, and there haven't been any signs of improvement. Rather, civic freedoms are being increasingly curtailed, and dissenters are being legally harassed by the State. One systematic way of suppression of civil society, is to curtail flow of funding to CSOs, which publicly denounce the schemes/policies of the government. A more recent threat to NGOs comes in the form of the recently published Draft Companies (Corporate Social Responsibility Policy) Amendment Rules 2020 which makes money spent on trusts and societies- which a majority of NGOs are registered under, as not qualifying for CSR.

\section{CORPORATE SOCIAL RESPONSIBILITY IN INDIA AND THE ROLE OF CIVIL SOCIETY}

In 2013, India became the first country in the world to make corporate expenditure mandatory on CSR related activities. An amendment to the Companies Act in 2013 made it mandatory for companies with a net-worth of over INR 5 billion, or net profit of INR 50 million or more, to spend $2 \%$ of their net profits spanning 3 years, as a part of CSR compliances in the areas of education, poverty alleviation, combating hunger and gender inequality (Dezan Shira and Associates, 2020).

In the same year, the CEO of Indian Institute of Corporate Affairs, Bhaskar Chatterjee, asserted that businesses and civil society must work in tandem to further the government's Corporate Social Responsibility Agenda. The role of CSOs in implementing the bottom of the pyramid measures towards the betterment of society was emphasised by the government and there was wide consensus about civil society being a critical partner in the implementation of activities for social good.

However, as Civil societies moved towards the political sphere and criticised governmental policies, they were seen as hindering India's economic development and a severe crackdown was launched with heightened urgency and intensity (Patra \& Behar, 2015). The leak of the Intelligence Bureau Report in 2014 which accused NGOs of reducing the annual GDP by over 2$3 \%$, alongside the stringent laws relating to investments and the subsequent clamp down on civil society led to NGOs being thought of as detrimental to India's development and not credible. This led to larger firms preferring to set up their own foundations. In addition to this, setting up their own foundations gave companies more control over the programmes they wanted to undertake and became a more convenient and hassle free channel for transferring funds (Ramanathan, 2016). Additionally, investments were diverted into government schemes such as Swacch Bharat Abhiyan and more recently, the PM Cares Fund (Patra \& Behar, 2015). Thus, the initial expected role of civil society as emphasised by the government was sidelined as 
International Journal of Social Science and Economic Research

ISSN: 2455-8834

Volume:06, Issue:03 "March 2021"

corporations started setting up their own foundations and shifting funds from already existing foundations.

\section{ROLE OF CIVIL SOCIETY IN THE PANDEMIC}

In the midst of our society battling the corona virus pandemic, we are seeing a similar picture. Civil society continues to do the groundwork despite severe crunch in corporate funding while civil space continues to be repressed. According to an India Today report, NGOs outperformed state governments in 13 states in providing humanitarian relief in the form of free meals. In Gujarat, 93\% of the people surveyed were fed by NGOs. NGOs also provided people with shelter in addition to providing meals. Despite this groundwork, the attack on social activists continues to take place. On March 31st, India's Ministry of Home Affairs instructed the Delhi Police to continue making arrests in relation to the February protests against the Citizenship Amendment Act (2019), despite prisons being full to the brim and no access to legal aid, since it does not come under 'essential' services. As of June 2nd, 1,300 arrests were made against political dissenters with allegations of Muslims being targeted.

At the beginning of the crisis, the CEO of NITI Aayog, Amitabh Kant, appealed to over 92,000 NGOs to help the government in the COVID-19 crisis. However, the establishment of the PM CARES Fund and its $100 \%$ tax exemption as compared to the $50 \%$ tax exemption on donations to NGOs has diverted the funds away from civil society as big and small companies alike donate to PM cares as a part of their $2 \%$ CSR obligations.

A nexus of businesses and the state is apparent which sidelines, and even suppresses civil society. Despite the initial emphasis on the role of civil society in carrying out programmes funded by CSR obligations, civil society receives negligible funds as businesses set up their own foundations or invest in government schemes. This is also seen in the current pandemic as businesses are fulfilling their CSR obligations by contributing to the PM CARES Fund instead of donating to CSOs working closely with vulnerable communities

\section{CURIOUS CASE OF THE PM CARES FUND}

The corona virus outbreak spelled a nation wide disaster, one that distressed all sections of society, albeit at various levels. Citizens of this country, especially the poor, needed immediate relief which they expected to come from the government. The Prime Minister National Relief Fund (PMNRF) set up in 1948 by then Prime Minister Nehru, is universally recognized as the country's national disaster relief fund. People were naturally expecting the Prime Minister's office to announce immediate aid for those in acute distress, from the PMNRF, which has an unspent balance of Rs 3,800 Cr. as of December 2019. 


\section{International Journal of Social Science and Economic Research}

ISSN: $2455-8834$

Volume:06, Issue:03 "March 2021"

However, in a bold move criticised by many, Prime Minister Modi announced the launch of a new relief fund called the Prime Minister's Citizen Assistance and Relief in Emergency Situations Fund, or the PM CARES Fund, on March 28. The fund has been set up as a disaster relief fund to provide support to those who are the most needy and vulnerable in the midst of this pandemic. The Centre called on celebrities, regular citizens, corporates, international entities and anyone and every one to donate heartily to the fund. The centre also facilitated a legal climate which was conducive to donations, as it offered $100 \%$ tax exemption on all donations to the fund.

\section{STRUCTURE OF PM CARES FUND}

According to the official website of the PM CARES Fund, it is being controlled by a Board of Trustees which includes the Chairperson (Prime Minister) and three other ministers namely the Minister of Defence, Minister of Home Affairs and Minister of Finance. These three ministers would act as the ex-officio Trustees of the Fund, meaning that their position as a trustee is tied to their position in the cabinet. Additionally, they will have the power to nominate three trustees to the Board, who will be eminent persons in the field of research, health, science, social work, law, public administration and philanthropy. All persons appointed as a Trustee, which for now are the three ministers holding the portfolios of Defence, Home Affairs and Finance in the cabinet, will act in a pro bono capacity.

\section{WHERE ARE THE RECEIPTS?}

The structure and mandate of the PM CARES fund has been largely ambiguous'. It clearly lacks accountability, and the government so far has been unwilling to provide any public record of inflow and outflow of contributions to and from the fund. Having received donations from all sections of society in large numbers, including foreign donations, the fund has quickly catapulted into a centralized repository of monetary aid, that some estimates claim has surpassed a collection of $\$ 1$ billion. But alas, the public has no way of knowing if that figure represents the true picture.

On April 1, an application was filed under the Right To Information Act, demanding disclosure of the constitution of the fund. The RTI applicant Harsha Kandukuri, a law student, 'sought the copies of the trust deed of PM Cares Fund, and all Government Orders, Notifications and Circulars relating to its creation and operation'. However, the application was disposed of on May 29, by a Public Information Officer of the PMO stating: "PM CARES Fund is not a public authority under the ambit of Section 2(h) of the RTI Act, 2005. However, relevant information in respect of PM CARES Fund may be seen on the website pmcares.gov.in." 
The State has allocated Rs 3,100 Cr from the PM CARES fund towards COVID relief, the division for which follows - Rs $2000 \mathrm{Cr}$ for ventilators, Rs $1000 \mathrm{Cr}$ for migrants and Rs $100 \mathrm{Cr}$ for vaccine development. Considering the fund is not a public authority, and the Comptroller Auditor General of India does not have the authority to audit the fund, the public is essentially left in the dark about the inflow and outflow of public donations and public expenditure respectively, viz-a-viz fund. The PMNRF displays its annual transaction history, with dedicatedly documented incoming and outgoing transactions, on its website.

The public is demanding accountability from the government, and especially the Prime Minister's Office. So far, those demands have been met with silence and dismissals.

\section{BIG BUSINESSES RESPOND TO CRISIS}

We looked at the top 50 companies on the ET 500 Companies 2019 rankings, and analysed their responses to the crisis. Below we have showcased the steps taken by various companies, based on their public announcements. We have classified their responses into three categories towards employees, towards customers, towards society. Towards employees:

- Facilitation of work from home

- Awareness generation regarding safety measures to be followed through SMS alerts, social media, e mails, video messages etc.

- Constitution of task force to roll out advisory for employees' well-being

- Enforcing strict safety standards at operation sites

- Sanitizing worker residence colonies

- Creation of end-to-end platform for tracking employee health and well-being

- Tele-consultations with medical experts

- Ex gratia payment to workers succumbing to the virus in line of work

- Creation of new technology to allow remote collaboration of employees

- Upskilling opportunities offered to employers through e-learning

Towards customers:

- Safe online deliveries of essentials 
- Facilitating cashless payment

- Priority services to vulnerable customers

- Moratorium on repayment of loans

- Emergency credit line

- Free service and warranty extension on

- Tech support to essential industries

Towards society:

- Collaboration with NGOs to provide relief

- Meals fed to the poor and ration provided to communities

- Donation of safety kits to people

- Converting operation sites to isolation centres

- Setting up makeshift medical facilities

- Using factories to manufacture ventilators, sanitizers, masks, protective clothing etc. • Awareness generation about virus in public interest

- Monetary donations to CSOs for relief work

A common trend across the board was companies pledging crores in contribution to the PM CARES Fund, which is estimated to have collected over $\$ 1.27 \mathrm{Bn}$ in donations so far, from various sources. Out of the top 50 companies, we compiled a list of all those who had publicly pledged support to the Fund, and/or had raised donations from their employees. Below is a graphical representation of the same. 


\section{International Journal of Social Science and Economic Research}

ISSN: 2455-8834

Volume:06, Issue:03 "March 2021"

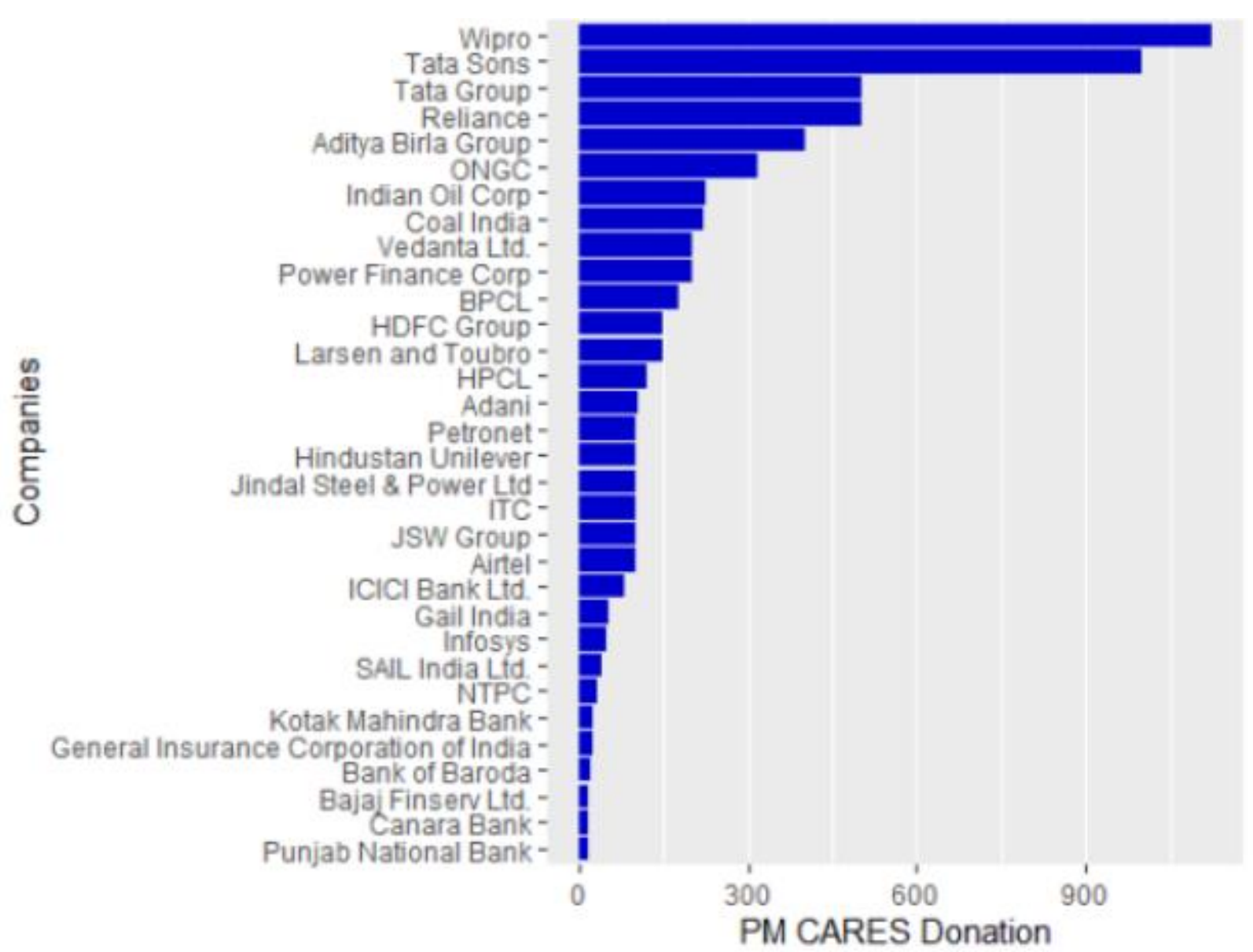

Company donation + Employee donations to the PM CARES Fund (in Cr)

\section{DONATIONS TO PM CARES FUND - Compassion or Coercion?}

Over the course of this project, we looked at the donations made by various large and small businesses to the PM CARES fund. We noticed bizarre incidents where some companies slashed a major chunk of their workforce, but donated a hefty amount to the fund. For example, global health and wellness startup Cure.fit shut down all their operations across small towns in India, resulting in massive job cuts. However, they announced that the company will be donating Rs 5 crores to the PM CARES fund. This received massive outrage from people who compared this donation with the Rs 2 crore fund the company decided to set up for its employers.

Considering that the PM CARES fund declared that all corporate donations will be receiving $100 \%$ tax exemption and will be considered in lieu of the company's CSR obligations, it is no surprise that many big businesses poured crores of donations into the fund. However, some reports claim that the Centre has made subtle moves which hint at the government strong arming 
International Journal of Social Science and Economic Research

ISSN: 2455-8834

Volume:06, Issue:03 "March 2021"

businesses into donating to the fund. Reuters had recently reported that the Ministry of Corporate Affairs had sent out a letter on March 30 to various corporates, titled as "An Appeal", to donate to the PM CARES fund. In fact, those companies that had already met their CSR obligations, were encouraged to go "over and above" and make donations to offset their future CSR obligations. Centre had directed_all Steel PSUs to fulfill their CSR obligations for the year by donating to the PM CARES fund. Steel Minister Dharmendra Pradhan said that the extra donations would be offset later, but for now, all Steel PSUs are to 'deposit unspent CSR funds of the current fiscal and the CSR funds of the next fiscal into the PM CARES Fund'. The Ministry of Steel later released a statement declaring a joint donation of Rs 267.55 crore, by 8 steel PSUs, to the PM CARES fund.

In fact, various state government employees have spoken out anonymously against the constant pressure they are facing to donate to the fund. A popular news publication_spoke to many administrative officials, and they claimed that although the donations are supposed to be voluntary in nature, they are facing a subtle pressure at every turn in the form of constant reminders from senior officials, to donate to the fund.

A circular was issued by the Department of Revenue on 17th April, appealing to all officers and staff to "contribute their one day's salary every month till March 2021 to the PM CARES Fund to aid the government's efforts to fight the coronavirus pandemic". Many officials who are at a junior level and receive less pay, felt that this imposition on them was grossly unfair. Even though the circular claims that the donations are voluntary, officials do not want to be identified as the one that did not donate and come under the scanner of their respective departments.

Similar appeals have been made in various other public and private institutions. We acquired a copy of a mail sent out to employees at one of the branches of State Bank of India, which requested employees to donate a part of their salary to the PM CARES fund. On further probing, we discovered the presence of a toxic culture in many public institutions, where peer pressure pushes people to make certain behavioral decisions that they are otherwise unwilling to make. So even if an employee did not wish to donate, the subtle and often silent disapproval of their colleagues would push them to behave according to what is expected of them.

It is therefore no secret that many companies have pledged hundreds of crores as donations to the PM CARES Fund. The question that remains to be asked is that if these big companies have already committed their CSR obligations for this year to the government, how will the CSOs fare in the days ahead?

COMPARISON OF DONATIONS TO CSR EXPENDITURE 
Many aid groups have expressed concerns about money being diverted away from grassroots level humanitarian efforts and into the PM Cares Fund. Al Jazeera spoke to Namita Gopal, a Mumbai based CSR consultant, who expressed concerns over the future of CSOs in the country, which are now being left high and dry by corporates rushing to get into the good books of the government.

We looked at data from a representative sample size of 10 of the top spenders in the field of Corporate Social Responsibility, for the year 2018-2019, and compared their expenditure with their donations to the PM CARES Fund. The output showed that a substantial amount of funding was going towards the PM Cares Fund from big businesses in the year 2020.

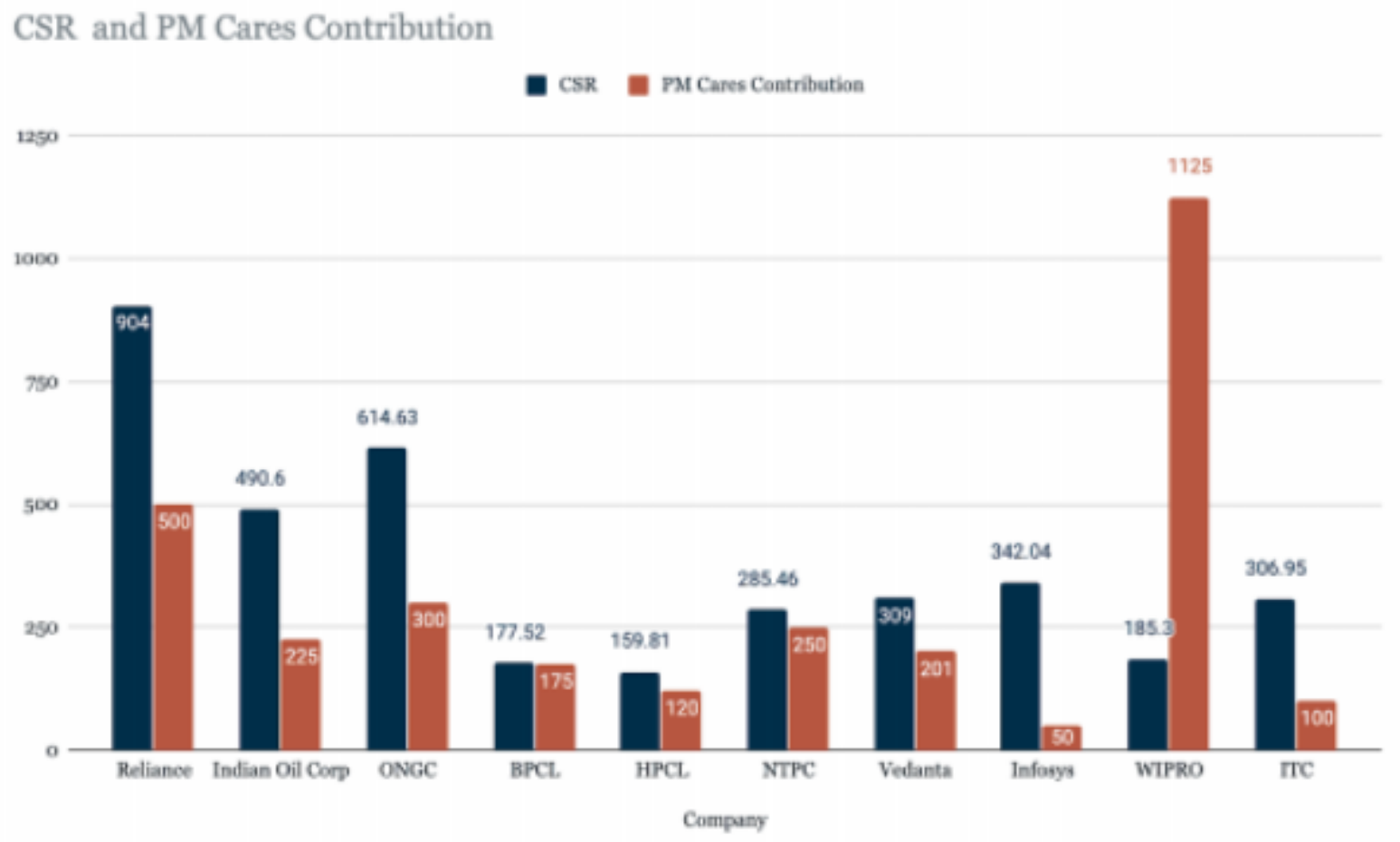

A comparative analysis confirms our fears of funding for CSOs drying up severely for the year ahead. If this fund was to continue offering $100 \%$ tax exemption along with donations being counted as part of CSR, then this could be a long term trend that jeopardizes the future of many small and large nonprofits working across the country.

\section{IS THERE LIGHT AT THE END OF THE TUNNEL?}

The COVID-19 outbreak has understandably upended funding channels for CSOs. Darren Walker, president of the Ford Foundation, one of the largest philanthropic entities which funds several nonprofits globally, said that "there's never been such an existential challenge to the 


\section{International Journal of Social Science and Economic Research}

ISSN: $2455-8834$

Volume:06, Issue:03 "March 2021"

future of the nonprofit sector." However, this period has also been an eye opener for the larger society, regarding the utility of nonprofit and CSOs in our country.

When Prime Minister Modi announced a nation-wide lockdown on 26th March, without any prior warning or preparedness, it sent millions of migrant workers packing for their villages. No jobs, no income and worse, no means to get back home, many decided to undertake the arduous journey of walking back home to their villages, located hundreds of kilometers away. The images that surfaced of the long walk home of hungry and desperate migrants, many of them women and children, evoked a sense of gratitude from those who had a roof over their head and food on their plate.

The government might have failed in their handling of the lockdown and the collateral damage, but civil society rose up to the occasion. Reports poured in from parts of the country about how citizen collectives, student associations, journalists, NGOs, and most importantly, many individuals are doing all that they can to help out those in need. Throughout the lockdown, and even as I write this, civil society has continued to upstage the government by leading a coordinated effort to provide relief aid to millions across the country. Cooked meals, dry ration, shelter for the homeless, hygiene and sanitation kits, are just some of the services provided by CSOs to the needy.

We are currently living through a historic moment that will shape the decade to come. The COVID-19 outbreak will define our generation for years after we are gone. It is up to us to decide the kind of precedent we want to set during a crisis of this scale, that has affected the entire world. This has clearly been the launchpad for civil society in most countries. Members of the community have shown grit and tenacity in ensuring that the most vulnerable sections of society are cared for. This period in history will also go down as the time when civic groups across the world defied a pandemic to protest against human rights violations. What is now largely being called the Second Civil Right Movement in America, is making millions of Americans of all races take to the streets, to protest systemic racial injustice in America. Coronavirus might have dampened the Hong Kong protests_for a while there, but protesters are back to clashing with the police to demand their freedom. Protests are raging all across the world from Israel to France. It is clear that civil society will not stop fighting for basic human rights. Their indomitable voices will continue to rise against injustice.

Having established their large scale reach, the utility of their networks, and the difference that they can make in the society through all the relief work that CSOs have undertaken during the pandemic, we are now hoping for deregulation for CSOs. We are now looking towards our country's government to provide CSOs the support they need, to carry out their social activities which have had a major impact on people, especially during the ongoing crisis. It's a dual 
International Journal of Social Science and Economic Research

ISSN: 2455-8834

Volume:06, Issue:03 "March 2021"

pronged attack that they are currently facing. With local funds drying up owing to the diversion of CSR funds, CSOs will look to foreign donations, which will in turn invite the wrath of the government, via the use, or rather misuse of FCRA. We therefore hope for greater fiscal freedom of CSOs, which would only be possible through easing of the FCRA and legislative sanctions for CSR funding to go to the organizations that need them. We also demand that the transaction history of the PM CARES Fund is revealed to the public, since it is largely public money that has gone into the fund. An overhaul of the current policy climate for civil society is in order, and we hope to see the winds of change blowing our way.

"Abandoning civil society will leave the enemy in control, not by victory but by default." Mike Klepper

\section{Works Referenced}

1. Baviskar, B. (2001). NGOs and Civil Society in India. Sociological Bulletin, 50(1), 3-15. Retrieved May 20, 2020, from www.jstor.org/stable/23620147

2. Cooper, R. (2018). What is Civil Society? How is the term used and what is seen to be its role and value (internationally) in 2018? K4D Helpdesk Report. Brighton, UK: Institute of Development Studies. 3. Cf. Lola Nayar, "War and GreenPeace“, Outlook Magazine, 30 June 2014

4. Dezan Shira and Associates, DSA. (2020, March 23). Corporate Social Responsibility in India. India Briefing. Retrieved from

5. Bhattacharyya, RB. (2013, 7th August). Civil Society to play a crucial role in CSR Agenda. The Economic Times. 6. Patra \& Behar, PP \& AB. (2015). Implications of corporate social responsibility on civil society in India. National Foundation for India.

7. Ramanathan, AR. (2016, November 18th). Large firms prefer setting up foundations for CSR. Livemint. 